\title{
"National" operations of Great terror: hierarchy of governing powers and punitive agencies in the center and the periphery
}

\author{
DOI: 10.31551/2410-2725-2019-5-2-151-162
}

\author{
Ablazhey Natalia Nikolaevna \\ Doctor of Sciences (history), Senior Researcher, Institute of History, Siberian Branch of the Russian \\ Academy of Sciences; associate professor, Institute of Humanities Novosibirsk State University. E-mail: \\ ablazhey@academ.org
}

\section{Potapova Natalia Anatolyevna}

holder of a master's degree in history, PG student, Institute of Humanities Novosibirsk State University. E-mail: skna17talya@mail.ru

\begin{abstract}
The article is devoted to the analysis of one of the key areas of repression in1937-1938 "national" operations of the NKVD of the USSR, on which 347 thousand people were convicted. The place of "national" operations in the history of the Great Terror, the powers of the punitive bodies, the mechanisms of implementation and statistics of repression, as well as the specific interests of the central government, regions and the NKVD are analysed on the materials of the office work of departments and extra-judicial authorities. It is concluded that the mass terror was initiated by the Politburo of the Bolsheviks party, which delegated the NKVD broad punitive powers, sanctioning the extra-judicial nature of the repression and the implementation of a series of linear punitive operations. In the years 1937-1938, the NKVD of the USSR organised eleven national punitive actions, which, under the control of the party and due to the vertical mechanism of organization of power, allowed to implement both all-union and regional punitive directions. The massive character of repressions was provided by the extra-judicial authorities (the NKVD Commission and Prosecutor of the USSR ("dvoika"), and Special meeting of the NKVD and Special "troikas". The repressions did not take the format of ethnic purges, although in the spring of 1938, when the "national" operations took the most important place in the punitive policy, there was a trend to this direction, as $60 \%$ of the repressed were representatives of national minorities. The authors conclude that in the period of the Great terror in the USSR in the framework of the "national" operations the planned repressive actions aimed at "withdrawal" of "alien" and "non-indigenous" elements were carried out that led to the decline of expat communities.
\end{abstract}

Keywords: Great terror; repressions; "national" operations; extra-judicial instances.

\section{Ұлттықтеррорду «Ұлттық» операциялары: орталық және терминдерге қуат және жаналық органдардың мемлекеттері}

\section{Аблажей Наталья Николаевна}

Ресей ғылым академиясының Сібір бөлімшесінің тарих институтының аға ғылыми қызметкері, тарих ғылымдарының докторы; Новосібір мемлекеттік университетінің гуманитарлық институтының доценті (Новосібірқаласы). E-mail: ablazhey@academ.org

\section{Потапова Наталья Анатольевна}

Тарих магистрі, Новосібір мемлекеттік университетінің гуманитарлық институты (Новосібір қаласы). E-mail: skna17talya@mail.ru

Андатпа. Мақала 1937-1938 жылдардағы репрессияның негізгі бағыттарының бірін талдауға арналған. - КСРО-ның НКВД ұлттық операцияларына 347 мың адам сотталды. НКВД ведомстволық жұмысының материалдары мен соттан тыс істер Ұлы Террордың тарихындағы «ұлттық» операциялар, жазалаушы органдардың өкілеттіктері, репрессияны жүзеге асыру тетіктері мен статистикасы, орталық үкіметтің, өңірлердің және НКВД-ның нақты мүдделерінің орнын талдайды. Қорытындылай келе, жаппай террорға КОКП бюросының (b) бастамасы енгізілді, ол НКВД кең жазалаушы өкілеттіктерді беріп, репрессияның соттан тыс сипатын және бірқатар «сызықтық» жазалау әрекеттерін жүзеге асыруға санкция берді. 1937-1938 жж КСРОның НКВД партиясының бақылауымен және энергетикалық ұйымның тік механизмімен бүкілодақтық және аймақтық жазалаушы бағыттарды жүзеге асыруға мүмкіндік берген он бір ұлттық іс-қимылды сатты. Жаппай қуғын-сүргінді соттан тыс жағдайларда (НКВД Комиссиясы және КСРО Прокуроры («екеуі»), КСРО НКВД-нің арнайы отырысы және Арнайы троктар) қамтамасыз етті. Репрессиялар этникалық тазартудың фрорматын қабылдамады, бірақ 1938 жылдың көктемінен бастап, «ұлттық» операциялар жазалау саясатында басты орын алған кезде, қуғын-сүргінге қарсы үрдіс пайда болды, өйткені қуғын-сүргіндердің 60\% ұлттық азшылық 
өкілдері болды. Авторлар КСРО-дағы Ұлы Террор кезеңінде «ұлттық» операциялардың шеңберінде «азаматтық емес» және «шетелдік» элементін «алып тастауға» бағытталған жоспарлы репрессиялық іс-шаралар жүргізілді, бұл диаспоралардың санын азайтуға алып келді. Түйін сөздер: Ұлы террор, репрессия, «ұлттық» операциялар, соттан тыс істер.

\section{«Национальные» операции Большого террора: иерархия полномочий власти и карательных органов в центре и на периферии}

\section{Аблажей Наталья Николаевна \\ д.и.н., старший научный сотрудник, Институт истории СО РАН; доцент, Гуманитарный институт Новосибирского государственного университета (г. Новосибирск). E-mail: ablazhey@academ.org Потапова Наталья Анатольевна}

магистр истории, аспирант, Гуманитарный институт Новосибирского государственного университета (г. Новосибирск). E-mail: skna17talya@mail.ru

Аннотация. Статья посвящена анализу одного из ключевых направлений репрессий 19371938 гг. - «национальным» операциям НКВД СССР, по которым было осуждено 347 тыс. чел. На материалах ведомственного делопроизводства НКВД и внесудебных инстанций анализируется место «национальных» операций в истории Большого террора, полномочия карательных органов, механизмы реализации и статистика репрессий, специфика интересов центральной власти, регионов и НКВД. Делается вывод, что массовый террор был инициирован Политбюро ВКП(б), которое делегировало НКВД широкие карательные полномочия, санкционировав внесудебный характер репрессий и реализацию серии «линейных» карательных операций. В 1937-1938 гг. НКВД СССР реализовало одиннадцать национальных акций, что позволило при контроле со стороны партии и вертикальному механизму организации власти реализовывать как общесоюзные, так и региональные карательные направления. Массовость репрессий обеспечили внесудебные инстанции (Комиссия НКВД и Прокурора СССР («двойка»), Особое совещание при НКВД СССР и Особые тройки). Репрессии не приняли формат этнических чисток, хотя с весны 1938 г., когда «национальные» операции заняли главное место в карательной политике, появилась тенденция этнизации террора, так как 60 \% репрессированных являлись представителями национальных меньшинств. Авторы делают вывод, что в период Большого террора в СССР в рамках «национальных» операций осуществлялись спланированные репрессивные акции, направленные на «изъятие» «иногражданского» и «инонационального» элемента, что привело к снижению численности диаспор.

Ключевые слова: Большой террор, репрессии, «национальные» операции, внесудебные инстанции.

\section{УДК/UDC 94(47)-1937/1938}

\section{«Национальные» операции Большого террора: иерархия полномочий власти и карательных органов в центре и на периферии}

\section{Н.Н. Аблажей, Н.А. Потапова}

Введение. Политические репрессии были неотъемлемой частью политики советского государства с первых лет его существования, однако пика они достигли в 1937-1938 гг., когда фревральско-мартовский пленум ЦК ВКП(б) 1937 г. обозначил линию на ужесточение репрессивной политики. Решения пленума одобрили «мероприятия ЦК ВКП(б) по разгрому антисоветской, диверсионно-вредительской, шпионской и террористической банды троцкистов и иных двурушников», обозначили курс на реорганизацию аппарата НКВД с целью сделать его «подлинно боевым органом, способным обеспечить возложенные на него партией и советским правительством задачи по обеспечению государственной и общественной безопасности» (Вопросы истории, 1992: 26). «Курс на репрессии» сопровождался масштабно 
организованной пропагандистской кампанией, в ходе которой советское общество, охваченное искусственно раскрученной шпиономанией, было подготовлено к массовым карательным акциям. В период Большого террора ключевыми направлениями репрессий стали: «чистки» элиты по так называемым «сталинским спискам», «кулацкая» операция и серия «национальных» операций. Летом 1937 г. на пике шпиономании стартовала самая крупная карательная акция НКВД - «кулацкая» операция, что и сделало террор «Большим» (Юнге, Биннер, 2003); вслед за ней запускаются «немецкая» и «польская» операции. Репрессии планировалось провести за три месяца, но завершены они были только в середине ноябре 1938 г. За период с октября 1936 г. по июль 1938 г., по данным самих карательных органов, в стране было репрессировано около 1,4 млн чел. (Трагедия советской деревни, 2000-2005. T. 5: 1937-1939. Кн. 2: 163).

Вертикаль Большого террора: историография вопроса. Тема Большого террора, базовая для западной советологии, с началом 1990-х гг. стала одним из ведущих направлений, как для отечественной историографии, так и для историографии постсоветских стран. В существующих работах главное место занимает сам феномен Большого террора, его причины, масштабы и последствия. Дискуссию вызывает вопрос, касающийся ответственности центра и регионов за организацию и проведение массовых репрессий. С момента появления первых работ по Большому террору исследователей волнует вопрос о том, кто был направляющей силой репрессий и каковы были полномочия НКВД в проведении чисток 1937-1938 гг.

С. Коэн (Коэн, 1988), Р. Медведев (Медведев, 1990), Р. Конквест (Конквест, 1991), Д. Волкогонов (Волкогонов, 1992), Ф. Волков (Волков, 1992), В. Роговин (Роговин, 1996) возлагают ответственность за развязывание репрессий на Сталина, который, по их мнению, таким образом, пытался расширить и укрепить собственную власть. Представители ревизионистского направления А. Гетти (Getty, 2002: 113-139), П. Холквист (Holquist, 2003: 129-156), Н. Верт (Верт, 2010), Ш. Фицпатрик (Фицпатрик, 2001) считают, что инициатива по организации и проведению массовых чисток принадлежит региональным руководителям. Авторы опровергают мнение о централизованном планировании операций НКВД 1937-1938 гг. и приводят аргументы в пользу того, что центр не управлял карательными акциями. О.В. Хлевнюк (Хлевнюк, 1992, 2010), Н.В. Петров (Петров, Янсен, 2009), В.Н. Хаустов (Хаустов, Самуэльсон, 2009) полагают, что террор не мог выйти из-под контроля Сталина. Причины репрессий они видят в попытке обезопасить страну от «пятой колонны». Международный исследовательский коллектив под руководством немецких историков М. Юнге и Р. Биннера сделал вывод об обоюдной ответственности за террор власти и общества (Юнге, Биннер, 2003; Юнге, Бордюгов, Биннер, 2008; «Через трупы врага», 2010). На примере проведения «кулацкой» операции впервые было показано, что террор 19371938 гг. имел вертикальную иерархию управления. Ответственность территориальных органов НКВД, центрального аппарата и Политбюро ЦК ВКП(б) признается как очевидная при проведении «кулацкой» операции.

«Национальные» операции изучены фррагментарно. К настоящему времени в поле зрения специалистов оказались четыре карательные акции: «польская» (Н.В. Петров, А.Б. Рогинский) (Петров, Рогинский, 1997: 22-43), «немецкая» (Н.Г. Охотин, А.Б. Рогинский) (Охотин, Рогинский, 1999: 35-75), «харбинская» (Н.Н. Аблажей) (Аблажей, 2007; Аблажей, 2008: 80-85) и «греческая» (И.Г. Джуха) (Джуха, 2006). Алгоритм изучения массовых акций 
против «националов» был предложен Н.В. Петровым и А.Б. Рогинским, которые считали, что приказ № 00485 стал «модельным» для директив НКВД по всем последующим «национальным» операциям. Именно они первыми указали на «безлимитный» принцип и на новый в практике НКВД процессуальный порядок осуждения - «альбомный». В существующих работах по «линейным» карательным акциям не затрагивается вопрос о роли Политбюро ЦК ВКП(б), НКВД в планировании и проведении репрессий. До тех пор пока данная проблема не будет изучена на примере всех массовых операций, вопрос об ответственности за террор нельзя считать закрытым.

«Национальные» операции и их место в Большом терроре. «Кулацкая» операция, проводимая по приказу № 00447 от 30 июля 1937 г., стала самой массовой карательной акцией Большого террора. Согласно официальным данным НКВД СССР, общее число осужденных по ней составило около 800 тыс. чел., в том числе около 400 тыс. чел. были приговорены к расстрелу (Трагедия советской деревни, 2000-2005. Т. 5: 1937-1939. Кн. 2: 163). «Национальные» операции заняли второе место в статистике репрессий. «Кулацкая» операция была нацелена на борьбу с «бывшими», а «национальные», направленны на «изъятие» «иногражданского» и «инонационального» элемента.

За период с июля 1937 г. по ноябрь 1938 гг. нарком внутренних дел Н.И. Ежов подписал семь оперативных приказов, запускающих репрессии по «немецкой» (№ 00439 от 25 июля 1937 г.), «польской» (№ 00485 от 11 августа 1937 г.), «харбинской» (№ 00593 от 20 сентября 1937 г.), «латышской» (№ 49990 от 30 ноября 1937 г.), «иранской» (№ 202 от 29 января 1938 г.), «афганской» (№ 226 от 16 февраля 1938 г.) и «греческой» (№ 50215 от 11 декабря 1937 г.) операциям (или линиям). Приказ № 00485 («польская» операция) стал «модельным» для всех последующих «национальных» карательных акций. Кроме того, ряд дополнительных инструкций, подписанных Н.И. Ежовым в августе 1937 г. - ноябре 1938 г., усиливал репрессии в отношении целевых категорий «национальных» операций. 15 августа 1937 г. вышел приказ НКВД СССР № 00486, запускающий репрессии против жен и детей изменников родины, который был распространен и на «национальные» операции. 23 октября 1937 г. НКВД СССР издало приказ № 00693, предписывающий арестовывать всех перебежчиков (нелегальных мигрантов) ${ }^{1}$. Оперативный приказ № 00698 от 28 октября 1937 г. обозначил в качестве целевых категорий «национальных» карательных акций служащих диппредставительств².

В 1938 г. Н.И. Ежов дважды - в феврале ${ }^{3}$ и мае ${ }^{4}$ - давал указания продлить преследования по «национальным» операциям, что давало новый импульс карательным акциям и активизировало репрессии. Весь период Большого террора Нарком внутренних дел пытался поддерживать темп репрессий, этим объясняется большое количество приказов и директивных инструкций. Помимо оперативных приказов, открывающих все новые и новые «национальные» карательные акции, Н.И. Ежов 1 фревраля 1938 г. отправляет в регионы шифровку № 234 о перебежчиках, по фракту повторяющую аналогичный приказ за № 00693 от 23 октября 1937 г. ${ }^{5} .23$ феевраля в регионы

\footnotetext{
${ }^{1}$ ЦА ФСБ - Центральный архив Федеральной службы безопасности Ф. 3. Оп. 5. Пор. 2. Л. 34-37

${ }^{2}$ ЦА ФСБ. Ф. 3. ОП. 5. Пор. 2. Л. 39-41

${ }^{3}$ ЦА ФСБ. Ф. 3. ОП. 5. Пор. 2. Л. 62-63

${ }^{4}$ ЦА ФСБ. Ф. 100. Оп. 1. Пор. 6. Л. 30

${ }^{5}$ ЦА ФСБ. Ф. 3. Оп. 5. Пор. 2. Л. 64-65
} 
спускается инструкция, согласно которой в паспорта надлежало вклеивать фотографии. В инструкции указывалось, что «работу по наклейке фотографий на общегражданские паспорта широко использовать для выявления, в первую очередь в промышленности и на транспорте, скрывающихся перебежчиков, беглых кулаков, лиц иностранного происхождения и прочих категорий, подлежащих учету $и$ репрессированию по моим приказам о массовых операциях» ${ }^{6} .17$ июня 1938 г. нарком внутренних дел подписал меморандум № 1355, предписывающий увольнять из армии и фрлота всех служащих иностранного происхождения из числа поляков, латышей, греков, немцев и т.д. ${ }^{7}$, хотя приказы по «национальным» операциям уже преследовали названные целевые категории населения. Только в середине сентября 1938 г. Н.И. Ежов подписал приказ № 00606 останавливающий аресты по «национальным» карательным акциям.

Репрессии по «национальным» линиям санкционировала высшая партийная власть. Приказам НКВД СССР предшествовало соответствующее постановление Политбюро ЦК ВКП(б). На постановлениях, открывающих линейные карательные акции, имеются подписи И.В. Сталина, В.М. Молотова, Л.М. Кагановича, К.Е. Ворошилова и др. За июль 1937 г. - ноябрь 1938 г. высшую партийную санкцию получили «немецкий», «польский» «харбинский» приказы, «латышский», «иранский» и «афрганский» меморандумы, директива по «греческой» операции. В каждом случае нарком внутренних дел Н.И. Ежов представлял Политбюро готовые тексты оперативных приказов. Дважды он выступал с обширными докладами, первый касался «направлений и масштабов деятельности на территории Советского Союза «польской разведки», второй - «японской». Затем эти доклады в качестве «закрытых писем» стали приложениями к оперативным приказам по «польской» и «харбинской» операциям. В середине августа 1937 г. Политбюро ЦК ВКП(б) распространило действие приказа НКВД № 00486, касающегося репрессий в отношении жен и детей изменников родины, на «польскую» и «немецкую», а 20 сентября 1937 г. - и на «харбинскую» операции.

Террор не закончился в 1937 г. Решение о продлении в стране массовых репрессий могло быть принято только высшей партийной инстанцией. 31 января 1938 г. Политбюро продлило репрессии по «национальным» карательным акциям до середины апреля того же года. Одновременно НКВД рекомендовалось утвердить к проведению, наряду С действующими, «румынскую», «финскую», «эстонскую», «болгарскую», «македонскую» и «китайскую» операции (Лубянка, 2004: 468-469). Еще одним решением от того же числа "О перебежчиках» Политбюро предлагало НКВД провести новые аресты среди нелегалов (Лубянка, 2004: 469).

В конце мая 1938 г. второй раз за год Политбюро вновь продлило репрессии по «национальным» карательным акциям, на этот раз до 1 августа. Прекратились они только в ноябре. Решение Политбюро ЦК ВКП(б) от 17 ноября 1938 г. «Об арестах, прокурорском надзоре и ведении следствия» запрещало органам НКВД проводить массовые операции, а также ликвидировало внесудебные инстанции, сохранив только Особое Совещание НКВД СССР. Выпущенный НКВД 26 ноября 1938 г. приказ № 00762 «О порядке осуществления постановления СНК СССР и Политбюро ЦК ВКП(б)» отменял все оперативные приказы НКВД по «национальным» карательным акциям (№№00439, 00485, 00593, 49990, 50215, 202, 226, 00606, 00486, 00693).

${ }_{7}^{6}$ ЦА ФСБ. Ф. 3. Оп. 5. Пор. 2. Л. 58-61

${ }^{7}$ ЦА ФСБ. Ф. 3. Оп. 5. Пор. 2. Л. 77-78 
Политбюро ЦК ВКП(б) контролировало ход «национальных» операций благодаря поступающей из аппарата НКВД во главе с наркомом Н.И. Ежовым отчетности. Еженедельно для И.В. Сталина, В.М. Молотова и других первых лиц готовились докладные записки о результатах репрессий за прошедший период, где отражались сведения о количестве арестованных и осужденных, а также приводились примеры «ликвидации» крупных организаций и групп ${ }^{8}$. Кроме того, ежемесячно членам Политбюро представлялись сводки о результатах «национальных» карательных акций в регионах 9 . Один раз в квартал центральный аппарат составлял сравнительные отчеты с указанием количественных изменений за предыдущий трехмесячный период. Дополнительно итоговые обзоры о результатах карательных акций органы НКВД подготовили в январе, апреле, июле и ноябре 1938 г. ${ }^{10}$. Именно после представления подобных документов членам Политбюро выходило очередное постановление о продлении «национальных» операций. Так, после январского отчета 1938 г. руководство страны рекомендовало органам НКВД провести дополнительные карательные акции, что закономерно вызвало новую волну репрессий.

В 1937-1938 гг. массовость репрессий обеспечили внесудебные инстанции. Приговоры по «национальным» операциям выносили Комиссия НКВД и Прокурора СССР («двойка»), Особое совещание (ОСО) при НКВД СССР и Особые тройки. С августа 1937 г. по сентябрь 1938 г. карательные функции были закреплены за «двойкой», созданной по приказу №00485, в состав которой входили нарком внутренних дел Н.И. Ежов и прокурор СССР А.Я. Вышинский, иногда их заместители. В ее полномочия входило подписание уже готовых протоколов, которые составлялись центральным аппаратом НКВД на основании пришедших из регионов справок на арестованных («альбомная» справка). В последних указывались краткие анкетные данные и суть обвинения. Протоколы могли содержать сведения от одного-двух до тысячи человек. Подписанный документ окончательно утверждал репрессивное решение в отношении арестованных. Параллельно с Комиссией НКВД и Прокурора СССР работало Особое совещание при НКВД СССР. Выносить репрессивные решения В отношении лиц, арестованных в рамках «национальных» операций, ОСО не имело право. В ее задачи входило только оформление выписок на приговоренных к лагерному заключению, ссылке или выселению из страны. Выписки отправлялись на места для ознакомления с ними осужденных.

Весной 1938 г. Комиссия НКВД и Прокурора СССР «захлебнулась» в поступающих со всех регионов «альбомов» по «национальным» операциям. С мест сыпались жалобы на перегруженность тюрем, на дороговизну содержания уже фрактически приговоренных к расстрелу заключенных и т.п. (Петров, Рогинский, 1997: 22-43).К этому времени карательные органы уже оказались дискредитированы начатыми арестами организаторов чисток уровня региональных начальников НКВД. В сложившейся обстановке было принято решение о передаче карательных полномочий на места в компетенцию вновь образованных внесудебных инстанций - Особых троек, в состав которых входили начальник территориального НКВД, прокурор республики, края или области и партийный секретарь. Этот орган, созданный по приказу НКВД СССР № 00606 от 17 сентября 1938 г., обязывался в двухмесячный срок разобрать

\footnotetext{
${ }^{8}$ ЦА ФСБ. Ф. 3. ОП. 5. Д. 206. Л. 138-143

${ }^{9}$ ЦА ФСБ. Ф. З. ОП. 5. Пор. 573

${ }^{10}$ ЦА ФСБ. Ф. З. Оп. 4. Д. 581. Л. 77-88
} 
скопившиеся в Москве «альбомные» справки на арестованных. После завершения этой работы массовые аресты прекратились.

Итогом работы внесудебных инстанций по «национальным» операциям стало 347 тыс. чел. осужденных, в том числе Комиссия НКВД и Прокурора СССР вынесла приговоры около 239 тыс. чел., а Особые тройки рассмотрели дела в отношении около 108 тыс. чел. ${ }^{11}$. Приговоры по «линейным» карательным акциям были жестче, чем по «кулацкой» операции. Доля расстрельных решений превысила 70 \% от общего числа осужденных. Главными направлениями в карательной политике чекистов стали «польская» (около 144 тыс. чел.), «немецкая» (около 57 тыс. чел.) и «харбинская» (около 50 тыс. чел.) операции. По этим направлениям прошло около $72 \%$ от общего количества репрессированных в рамках «национальных» карательных акций.

Репрессивный механизм. Общесоюзный и региональный аспекты «национальных» операций. Органам НКВД в период Большого террора были предоставлены широкие полномочия , при помощи которых приводился в действие механизм репрессий . Оперативное делопроизводство НКВД позволяет обозначить семь «национальных» карательных кампаний, по числу подписанных оперативных приказов; вместе с тем, отчетное делопроизводство НКВД, а также материалы внесудебных инстанций позволяют выделить в общей сложности одиннадцать «национальных» операций, а именно: «польскую», «немецкую», «харбинскую», «латышскую», «греческую», «афганскую», «иранскую», «эстонскую», «фринскую», «румынскую» и «смешанную» («разную») ${ }^{12}$.

В рамках одиннадцати карательных операций Комиссия НКВД и Прокурора СССР оформляла особые протоколы, что свидетельствует о наличии общесоюзного характера и санкции НКВД. На проведение семи («польская», «немецкая», «харбинская», «латышская», «греческая», «иранская», «афрганская») карательных акций имеется соответствующее решение Политбюро ЦК ВКП(б); санкцию на проведение «румынской», «финской» и «эстонской» линий НКВД получило только 31 января 1938 г. Однако первый протокол по «румынской» карательной акции (на арестованных УНКВД Молдавской АССР) был утвержден Комиссией НКВД и Прокурора СССР уже 8 октября 1937 г. $^{13}$, на задержанных по линии УНКВД Ленинградской области в рамках «эстонской» операции - 4 ноября 1937 г., «финской» - 10 ноября 1937 г. $^{14}$. Из этого следует, что решение Политбюро фрактически только переводило уже идущие акции регионального масштаба в общесоюзный фрормат. Кроме того, постановление Политбюро ЦК ВКП(б) от 31 января 1938 г. рекомендовало НКВД провести «болгарскую», «македонскую» и «китайскую» операции. Несмотря на расширение масштаба репрессий, «болгарская» и «македонская» линии карательными органами как отдельные операции, так и не были проведены, а так называемая «китайская» операция стала частью «харбинской» (Потапова, 2018: 156-162).

«Болгарская» и «македонская» карательные акции стали частью так называемой «смешанной» операции, запущенной аппаратом НКВД 8 января 1938 г. $^{15}$. По данным протоколов Комиссии НКВД и Прокурора СССР, она коснулась лиц, которым инкриминировали шпионаж в пользу Венгрии, Англии,

\footnotetext{
${ }^{11}$ ЦА ФСБ. Ф. 8ос. Оп. 1. Пор. 70. Л. 20

${ }^{12}$ ЦА ФСБ. Ф. 8ос. Оп. 1. Пор. 70. Л. 17-18

${ }_{13}^{13}$ УФСБ - Управление Федеральной службы безопасности по Омской области. Ф. 6. Пор. 9558. Л. 2-7

${ }^{14}$ УФСБ по Омской области. Ф. 6. Пор. 9749. Л. 1-14

${ }^{15}$ УФСБ по Омской области. Ф. 6. Пор. 10516-10527
} 
Франции, США, Югославии, Чехословакии, Италии, Турции и т.д. Внутри «смешанной» репрессивной акции можно выделить до 20 карательных «линий», в том числе «венгерскую», «английскую», «американскую», «фрранцузскую» и др. Инициатива по выделению «смешанной» операции в отдельную серию репрессий принадлежала центральному аппарату НКВД. Вероятно, ее суть заключалась не в проведении отдельной карательной акции со всеми вытекающими последствиями, а в составлении особого вида протоколов; другими словами, выделялась она только на бумаге. В отчетах, докладных записках, сводках, предназначенных для Политбюро ЦК ВКП(б), сведения о «смешанной» операции отсутствовали, как и не отражалась информация о дополнительных репрессивных направлениях, помимо вышеназванных. Впервые статистические сведения о «национальной» акции появляются в отчете НКВД от 15 ноября 1938 г. $^{16}$, хотя территориальные карательные органы с января 1938 г. включали в свои отчеты сведения о результатах проводимых ими дополнительных репрессий в рамках «национальных» операций. Вероятно, центральный аппарат НКВД во главе с Н.И. Ежовым территориальные инициативы по проведению репрессий объединил в единую «смешанную» акцию. В частности, на территории Украины чекисты проводили «чешскую» операцию на основании «модельного» приказа № 00485, подвергая арестам чешских политэмигрантов, перебежчиков, военнопленных и т.д. (Через трупы врага на благо народа, 2010. Т. 2: 1938 1941 гг. Второй этап репрессий. Завершение Большого террора и восстановление «социалистической законности»: 150). В Грузинской ССР НКВД проводил аресты по «турецкой» линии, которая не определялась как общесоюзная (задержаниям подвергались в основном армяне, беженцы от геноцида 1915 г. и турки) ${ }^{17}$. «Венгерская» репрессивная акция проводилась в Московской области, арестам в первую очередь подвергались политэмигранты. Региональные инициативы Комиссией НКВД и Прокурора СССР были вписаны в рамки «смешанной» операции, итогом проведения которой стало около 8,3 тыс. осужденных.

Некоторые репрессивные направления, особенно массовые, не рекомендованные Политбюро к проведению, вписывались в рамки уже идущих «национальных» операций. Так, в рамках приказа № 00593 арестам подвергалось корейское население, проживающее на территории СССР, около 5 тыс. корейцев было репрессировано по «харбинской» операции ${ }^{18}$. При этом данное карательное направление было проведено в общесоюзном масштабе.

«Китайская» операция, рекомендованная к проведению решением Политбюро ЦК ВКП(б) от 31 января 1938 г., не была выделена в отдельную карательную акцию, хотя начальник УНКВД по Дальневосточному краю, где репрессии в отношении китайцев были особенно масштабными, де фракто провел отдельную «китайскую» операцию. Возможно, причины отказа выделить «китайскую» операцию в отдельную линию, заключалась в факте побега за границу главного организатора репрессий в отношении «японских шпионов» Г.С. Люшкова и его дальнейшем сотрудничестве с Японией. Начальник НКВД СССР Н.И. Ежов, опасаясь за свою жизнь, не осмелился летом 1938 г. отчитываться по «китайской» операции, поскольку ее провел японский шпион, при том, что темпы арестов здесь могли сравниться только с «польской» (в дальнейшем, как известно, фракт побега Г.С. Люшкова стал

\footnotetext{
${ }^{16}$ ЦА ФСБ. Ф. 8ос. Оп. 1. Д. 70

${ }_{17}^{17}$ Архив МВД Грузии - Архив Министерства внутренних дел Грузии. 1-й отдел. Ф. 12. Д. 92

${ }^{18}$ УФСБ по Омской области. Ф. 6. Пор. 11709-10441
} 
одной из причин отстранения от власти и самого Н.И. Ежова) (Потапова, 2018: 156-162). В ходе «китайской» операции, вписанной в рамки «харбинской» карательной акции, репрессиям подверглись около 16 тыс. чел., или около 32 \% от общего числа осужденных «японских шпионов».

Заключение. Таким образом, репрессии 1937-1938 гг. отличались от предшествующих своими масштабами и организацией. Большой террор имел вертикальную иерархическую структуру управления, на вершине которой находилось Политбюро, выступавшее главным инициатором репрессий. Материалы заседаний Политбюро за 1937-1938 гг. наглядно показывают, насколько тщательно руководящий орган ВКП(б) занимался вопросами государственного террора. Ключевую цель «национально окрашенных» карательных акций Политбюро видело в очищении страны от вероятной «пятой колоны» в преддверии предстоящей войны. По этой причине в список врагов и возможных предателей были включены не только все «бывшие», «чуждые» и «социально-опасные», но также «националы» и иностранцы.

Органы НКВД, которым в период Большого террора Политбюро ЦК ВКП(б) предоставило широкие полномочия, во главе с наркомом внутренних дел Н.И. Ежовым, принимали участие в разработке репрессивной политики и осуществляли репрессивные акции в массовом масштабе. Кроме того, Политбюро наделило органы НКВД внесудебными полномочиями, что также обеспечило массовый характер преследований в период Большого террора. Очевидно, что в случае с «национальными» операциями приговоры не могли быть приведены в исполнение без утверждения Комиссии НКВД и Прокурора СССР, а по фракту - без санкции самого Н.И. Ежова. В этих условиях центральный аппарат НКВД выполнял координирующую, организующую и контролирующую функции, подчиняясь решениям Политбюро ЦК ВКП(б). Одна из важных задач заключалась в передаче требований руководства страны территориальным карательным органам. Постановления Политбюро спускались сначала в центральный аппарат НКВД, а уже затем поступали в регионы. Обратная схема существовала при предоставлении отчетности. Вся отчетность из регионов шла на имя наркома внутренних дел Н.И. Ежова. В полномочия территориальных органов входило проведение арестов, ведение следствия и вынесение предварительного приговора. Однако полномочия региональных карательных органов были ограничены. Кроме того, любая местная инициатива не могла быть осуществлена без санкции центрального аппарата или Политбюро ЦК ВКП(б).

При проведении «национальных» карательных акций территориальные органы НКВД стремились очистить подведомственные им территории от «неблагонадежных» групп населения. Именно отсюда появляются региональные инициативы по уничтожению целого ряда «национальных» и «инонациональных» элементов, в отношении которых Политбюро и центральный аппарат НКВД не принимало конкретных репрессивных решений. Однако эти инициативы поддерживались Н.И. Ежовым. Одной из таких акций стало проведение «смешанной» операции. Определенную свободу территориальным органам НКВД давало также отсутствие лимитов в «национальных» операциях, что приводило к увеличению масштабов арестов. В некоторых регионах «национальные» линии использовали для обхождения лимитов по «кулацкой» операции.

Карательные репрессии против «инонационалов» и «инограждан» были проведены «по линиям» практически всех стран «враждебного окружения», однако они не носили характер этнических чисток. Критерием принадлежности 
к враждебному лагерю здесь выступала в первую очередь не этничность, а факт рождения или проживания во «враждебной» «капиталистической» стране или поддержание любой связи с заграницей. Даже после завершения Большого террора «национальные» карательные акции не стали репрессиями по этническому принципу, хотя с весны 1938 г. наметилась этнизация в «линейных» операциях, так как 60 \% репрессированных являлись представителями национальных меньшинств. Но при этом треть репрессированных с весны по осень 1938 г. составляли представители титульных наций, прежде всего речь идет о русском, украинском и белорусском населении. В целом принадлежность к отдельным народам; якобы установленная, чаще всего гипотетическая «связь с заграницей»; социальный статус и «антисоветское» поведение увеличивали «шансы» подвергнуться репрессиям. Карательные акции в первую очередь прошли по государственным сферам, связанным с обороноспособностью страны. Главным итогом «национальных» карательных акций стало сокращение численности нетитульных групп в национальных республиках и автономиях, сокращение общин и диаспор.

\section{Әдебиеттер тізімі / Список литературы}

1. Getty, 2002 - Getty J.A. Origins of the Great Purges: The Soviet Communist Party Reconsidered. Cambridge, 1987; Idem. «Excesses are not permitted»: Mass Terror and Stalinist Governance in the Late 1930s. // Russian Review. 2002. № 1. P. 113-139.

2. Holquist, 2003 - Holquist P. State Violence as Technique: The Logic of Violence in Soviet Totalitarianism // Stalinism the Essential Readings. Bodmin, Cornwall, 2003. P. 129-156.

3. Аблажей, 2007 - Аблажей Н.Н. С востока на восток: Российская эмиграция в Китае. Новосибирск: Изд-во СО РАН, 2007. 298 с.

4. Аблажей, 2008 - Аблажей Н.Н. «Харбинская операция» НКВД в 1937-1938 гг. // Гуманитарные науки в Сибири. 2008. № 2. С. 80-85.

5. Верт, 2010 - Верт Н. Террор и беспорядок. Сталинизм как система. М.: РОССПЭН, Фонд Первого Президента Б.Н. Ельцина, 2010. 447 с.

6. Волков, 1992 - Волков Ф.Д. Взлет и падение Сталина. М.: Спектр'1, 1992. 336 с.

7. Волкогонов, 1992 - Волкогонов Д.В. Сталин. Политический портрет. М.: Новости, 1992. 704 с.

8. Джуха, 2006 - Джуха И.Г. Греческая операция. История репрессий против греков в СССР СПб.: Алетейя, 2006. 416 с.

9. Конквест, 1991 - Конквест Р. Большой террор. Рига: «РАКСТНИЕКС», 1991. 416 с.

10. Коэн, 1988 - Коэн С. Бухарин. Политическая биография 1888-1938. М.: Прогресс, 1988. 574 с. 11.Лубянка, 2004 - Лубянка. Сталин и главное управление госбезопасности НКВД. Архив Сталина. Документы высших органов партийной и государственной власти. 1937-1938 / под ред. А.Н. Яковлева. М.: Материк, 2004. 734 с.

12. Медведев, 1990 - Медведев Р. О Сталине и сталинизме. М.: Прогресс, 1990. 483 с.

13. Охотин, Рогинский, 1999 - Охотин Н., Рогинский А. Из истории «немецкой операции» НКВД 1937-1938 гг. // Наказанный народ. Репрессии против российских немцев. М.: Звенья, 1999. С. 35-75.

14. Петров, Рогинский, 1997 - Петров Н.В., Рогинский А.Б. Польская операция НКВД 1937-1938 гг. // Репрессии против поляков и польских граждан. М.: Звенья, 1997. С. 22-43.

15. Петров, Янсен, 2009 - Петров Н., Янсен М. «Сталинский питомец» Николай Ежов. М.: РОССПЭН, 2009. 447 с.

16. Потапова, 2018 - Потапова Н.А. Антикитайская карательная акция НКВД СССР периода Большого террора в Дальневосточном крае: механизмы и масштабы репрессий // Проблемы Дальнего Востока. 2018. № 3. С.156-162.

17. Роговин, 1996 - Роговин В.3. 1937. М.: Б. и., 1996. 479 с.

18. Стенограмма февральско-мартовского пленума ЦК ВКП(б) 1937 года // Вопросы истории. 1992. № 2-3.

19. Трагедия советской деревни. Коллективизация и раскулачивание. 1927-1939: Документы и материалы. в 5 т. / под ред. В. Данилова, П. Маннинг, Л. Виолы. М.: РОССПЭН, 2000-2005. Т. 5: 1937-1939. Кн. 2. 702 c. 
20. Фицпатрик, 2008 - Фицпатрик Ш. Повседневный сталинизм. Социальная история Советской России в 30-е годы: город. М.: РОССПЭН; Фонд Первого Президента России Б.Н.Ельцин, 2008. $336 \mathrm{c}$.

21. Хаустов, Самуэльсон, 2010 - Хаустов В., Самуэльсон Л. Сталин, НКВД и репрессии 19361938 г. М.: РОССПЭН, Фонд первого президента России Б.Н. Ельцина, 2010. 432 с.

22. Хлевнюк, 1992 - Хлевнюк О.В. 1937-й: Сталин, НКВД и советское общество. М.: Республика, 1992. $270 \mathrm{c}$.

23. Хлевнюк, 2010 - Хлевнюк О.В. Хозяин. Сталин и утверждение сталинской диктатуры. М.: РОССПЭН, Фонд первого президента России Б.Н. Ельцина, 2010. 479 с.

24. Через трупы врага на благо народа, 2010 - «Через трупы врага на благо народа». «Кулацкая операция» в Украинской ССР 1937-1941 гг.: в 2 т. / сост.: М. Юнге, С. А. Кокин, Р. Биннер, А.О. Довбня, Б. Бонвеч, И.Е. Смирнова, Г.А. Бордюгов; под. общ. ред. О.А. Довбни, Л.С. Макаровой. М.: РОССПЭН, 2010.

25. Юнге, Биннер, 2003 - Юнге М., Биннер Р. Как террор стал «большим». Секретный приказ № 00447 и технологии его исполнения. М.: АИРО-ХХ, 2003. 352 с.

26. Юнге, Бордюгов, Биннер, 2008 - Юнге М., Бордюгов Г., Биннер Р. Вертикаль большого террора. История операции по приказу НКВД № 00447. М.: Новый Хронограф; АИРО-ХХІ, 2008. $784 \mathrm{c}$.

\section{References}

Getty, 2002 - Getty J.A. Origins of the Great Purges: The Soviet Communist Party Reconsidered. Cambridge, 1987; Idem. «Excesses are not permitted»: Mass Terror and Stalinist Governance in the Late 1930s. // Russian Review. 2002. № 1. P. 113-139. (in Engl)

Holquist, 2003 - Holquist P. State Violence as Technique: The Logic of Violence in Soviet Totalitarianism // Stalinism the Essential Readings. Bodmin, Cornwall, 2003. P. 129-156. (in Engl)

Ablazhej, 2007 - Ablazhej N. N. S vostoka na vostok: Rossijskaya ehmigraciya v Kitae [From East to East: Russian emigration to China]. Novosibirsk: izdatel`stvo SO RAN, 2007. 298 s. (in Rus)

Ablazhej, 2008 - Ablazhej N. N. «Harbinskaya operaciya» NKVD v 1937-1938 [«Harbinian operation» NKVD in 1937-1938] / / Gumanitarnye nauki v Sibiri [Humanities in Siberia]. 2008. No. 2. pp. 8085. (in Rus)

Archive of the Ministry of internal Affairs of Georgia. 1st division. F. 12. D. 92 - archive of the Ministry of internal Affairs of Georgia. 1st division. F. 12. D. 92.

Vert, 2010 - Vert N. Terror i besporyadok. Stalinizm kak sistema [Terror and disorder. Stalinism as a system]. Moscow: ROSSPEN, Fond Pervogo Prezidenta B.N. Elcina, 2010. 447 s. (in Rus)

Volkov, 1992 - Volkov F. D. Vzlet i padenie Stalina [Rise and fall of Stalin]. Moscow: Spektr, 1, 1992. 336 s. (in Russ)

Volkogonov, 1992 - Volkogonov D. V. Stalin. Politicheskij portret [Stalin. Political portrait]. Moscow: Novosti, 1992. 704 s. (in Rus)

Juha, 2006 - Juha I. G. Grecheskaya operaciya. Istoriya repressij protiv grekov v SSSR [Greek operation. History of repression against the Greeks in the USSR]. St. Petersburg: Alethea, 2006. 416 s. (in Russ)

Konkvest R. Bolshoj terror [The Great terror]. Riga, 1991. 416 s. (in Rus)

Cohen, 1988 - Cohen S. Buharin. Politicheskaya biografiya 1888-1938. [Bukharin. Political biography 1888-1938]. Moscow: Progress, 1988. 574 s. (in Rus)

Lubyanka, 2004 - Lubyanka. Stalin i glavnoe upravlenie gosbezopasnosti NKVD. Arxiv Stalina. Dokumenty vysshix organov partijnoj i gosudarstvennoj vlasti. 1937-1938 [Lubyanka. Stalin and the main Directorate of state security of the NKVD. Stalin's Archive. Documents of the Supreme bodies of party and state power. 1937-1938] / pod red. A.N. Yakovleva. M.: Materik, 2004. 734 s. (in Rus)

Medvedev, 1990 - Medvedev, R. O Staline i stalinizme [About Stalin and Stalinism]. Moscow: Progress, 1990. 483 s. (in Rus)

Okhotin, Roginsky, 1999 - Okhotin N., Roginsky A. Iz istorii «nemeckoj operacii» NKVD 1937-1938 [From the history of the «German operation» NKVD 1937-1938] / / Nakazanny j narod. Repressii protiv rossijskix nemcev [Punished people. Repressions against the Russian Germans]. Moscow: Zvenya, 1999. S. 35-75. (in Rus)

Petrov, Roginsky, 1997 - Petrov N. In. Roginsky A. B. Polskaya operaciya NKVD 1937-1938 [Polish operation of the NKVD 1937-1938]// Repressii protiv polyakov i pol'skih grazhdan [Repression against poles and Polish citizens]. Moscow: Zvenya, 1997. S. 22-43. (in Rus)

Petrov, Jansen, 2009 - Petrov N., Jansen M. «Stalinskij pitomec» Nikolaj Ezhov [«Stalin's pet» Nikolaj Ezhov]. Moscow: ROSSPEN, 2009. 447 s. (in Rus)

Potapova, 2018 - Potapova N. A. Antikitajskaya karatel'naya akciya NKVD SSSR perioda Bol'shogo terrora v Dal'nevostochnom krae: mekhanizmy i masshtaby repressij [Anti-Chinese punitive action of the NKVD of the USSR during the period of Great terror in the far East: mechanisms and scale 
of repression] // Problemy Dalnego Vostoka [Problems of the Far East]. 2018. No. 3. S. 156-162. (in Rus)

Rogovin, 1996 - Rogovin V. Z. 1937. Moscow: B. I., 1996. 479 s. (in Rus)

Stenogramma fevralsko-martovskogo plenuma CK VKP(b) 1937 goda [Transcript of the FebruaryMarch Plenum of the CPSU(b) 1937] // Voprosy` istorii [Questions of history]. 1992. № 2-3. (in Rus)

Tragediya sovetskoj derevni. Kollektivizaciya i raskulachivanie. 1927-1939: Dokumenty` i materialy [ The tragedy of the Soviet village. Collectivization and dispossession. 1927-1939: Documents and materials]. in $5 \mathrm{t} /$ ed. V. Danilov, P. manning, L. viola. M.: ROSSPEN, 2000-2005. Vol. 5: 19371939. kn. 2. 702 s. (in Rus)

Fitzpatrick, 2008 - Fitzpatrick, S. Povsednevnyj stalinizm. Social'naya istoriya Sovetskoj Rossii v 30-e gody: gorod [Everyday Stalinism. Social history of Soviet Russia in the 30s: the city]. Moscow: ROSSPEN; Fond Pervogo Prezidenta Rossii B.N.Elcin, 2008. 336 s. (in Rus)

Khaustov, Samuelson, 2010 - Khaustov V., Samuelson L. Stalin, NKVD i repressii 1936-1938 [Stalin, NKVD and repressions 1936-1938]. Moscow: ROSSPEN, Fond Pervogo Prezidenta Rossii B.N.Elcin, 2010. $432 \mathrm{~s}$. (in Russ)

Khlevnyuk, 1992 - Khlevnyuk O. W. 1937-j: Stalin, NKVD i sovetskoe obshchestvo [1937: Stalin, NKVD and Soviet society]. Moscow: Respublika, 1992. 270 s. (in Rus)

Khlevniuk, 2010 - Khlevniuk O. V. Hozyain. Stalin i utverzhdenie stalinskoj diktatury [Master. Stalin and the establishment of Stalin's dictatorship]. Moscow: ROSSPEN, Fond Pervogo Prezidenta Rossii B.N. Elcin, 2010. 479 s. (in Rus)

Through the corpses of the enemy for the benefit of the people, 2010 - «Cherez trupy vraga na blago naroda». "Kulackaya operaciya» v Ukrainskoj SSR 1937-1941 [«Through the corpses of the enemy for the benefit of the people». "Kulak operation» in the Ukrainian SSR 1937-1941]: $2 \mathrm{t} /$ comp.: M. Junge, S. A. Kokin, R. Binner, A. O. Dovbnya, B. Bonvech, I. E. Smirnova, G. A. Bordyugov; pod. the General editorship of O.A. Dovbnya, L. S. Makarova. M.: ROSSPEN, 2010. (in Rus)

Junge, Binner, 2003 - Junge, M., R. Benner Kak terror stal «bol'shim». Sekretnyj prikaz № 00447 i tekhno-logii ego ispolneniya [How the terror became "great". Secret order № 00447 and the technology of its execution]. Moscow: AIRO-XX, 2003. 352 s. (in Rus)

Junge, Bordyugov, Binner, 2008 - Junge M., Bordyugov G., Binner R. Vertikal' bol'shogo terrora. Istoriya operacii po prikazu NKVD № 00447 [The Vertical of great terror. History of the operation by order of the NKVD № 00447] 